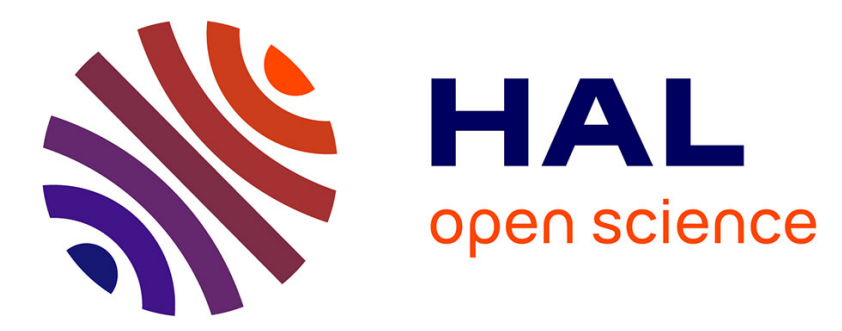

\title{
Validation of a software to perform exercise oximetry to diagnose arterial stenosis of the lower limbs
}

Alexandre Poulin, Antoine Guilcher, Loukman Omarjee, Vincent Jaquinandi, Yves Gandon, Guillaume Mahé, Olivier Stivalet

\section{- To cite this version:}

Alexandre Poulin, Antoine Guilcher, Loukman Omarjee, Vincent Jaquinandi, Yves Gandon, et al.. Validation of a software to perform exercise oximetry to diagnose arterial stenosis of the lower limbs. Atherosclerosis, 2018, 278, pp.325-327. 10.1016/j.atherosclerosis.2018.08.025 . hal-01880077

\section{HAL Id: hal-01880077 \\ https://hal-univ-rennes1.archives-ouvertes.fr/hal-01880077}

Submitted on 23 Jan 2019

HAL is a multi-disciplinary open access archive for the deposit and dissemination of scientific research documents, whether they are published or not. The documents may come from teaching and research institutions in France or abroad, or from public or private research centers.
L'archive ouverte pluridisciplinaire HAL, est destinée au dépôt et à la diffusion de documents scientifiques de niveau recherche, publiés ou non, émanant des établissements d'enseignement et de recherche français ou étrangers, des laboratoires publics ou privés. 
Validation of a software to perform exercise oximetry to diagnose arterial stenosis of the lower limbs

Alexandre Poulin ${ }^{1}$, Antoine Guilcher ${ }^{1}$, Loukman Omarjee ${ }^{1,2}$, Vincent Jaquinandi ${ }^{1,2}$, Yves Gandon ${ }^{1}$, Guillaume Mahe ${ }^{1,2,3}$, Olivier Stivalet ${ }^{1}$

${ }^{1}$ CHU Rennes, Imagerie Cœur-Vaisseaux, F-35033 Rennes. FRANCE.

${ }^{2}$ INSERM, Centre d'investigation clinique, CIC 1414, F-35033 Rennes. FRANCE.

${ }^{3}$ Université de Rennes 1

Address for correspondence:

Guillaume Mahe.

Pôle imagerie médicale et explorations fonctionnelles. Hôpital Pontchaillou, 2 rue Henri Le Guilloux. Rennes, F-35033. France. Tel: +33 (0)2 9928 4321. Fax: +33 (0)2 99284364 E-mail: $\underline{\text { maheguillaume@yahoo.fr }}$

Key words: Oximetry, Peripheral artery disease, software, vascular

To the Editor,

We would like to congratulate Abraham et al. for their interesting review "Clinical application of transcutaneous oxygen pressure measurements during exercise"[1]. We totally agree that exercise oximetry is very useful in specific situations when patients experience exertional limb symptoms during the walk [2-4]. As mentioned in the review, the Delta from Rest Oxygen Pressure (DROP) 
index used to diagnose lower extremity peripheral artery disease was validated against angiography and computed tomography angiography (CTA) [5,6]. Unfortunately, the calculation of the DROP is very complicated in clinical practice without the use of a dedicated software. Indeed, without a software, a time-consuming procedure using Excel ${ }^{\circledR}$ spreadsheets has to be performed to analyze that data from the oximeter. Therefore, the increase in the use of exercise oximetry depends on the development of dedicated available softwares. The present study assesses the correlation and the concordance of the results obtained by spreadsheets analysis to the results obtained with an in-house developed software.

\section{Materials and methods}

We analyzed the data from 34 patients with exertional limb symptoms referred to our vascular clinic for exercise-TcPO2 testing from 2014 to 2015 . This study was conducted according to the principles outlined in the French Laws.

\section{Ankle-brachial index measurement}

The measurement of the ankle-brachial index (ABI) was performed according to the AHA guidelines using a hand-held Doppler probe ( $8 \mathrm{MHz}$ ) by trained physicians $[7,8]$.

\section{Exercise-TcPO2 measurement}

Measurement of TcPO2 was performed using calibrated TcPO2 electrodes (TCOM/TcPO2; PF 6000TcPO2/CO2 Unit; Perimed®; Jarfalla, Sweden). The temperature of each electrode was set to $44^{\circ} \mathrm{C}$, which allows maximal vasodilation and decreases the arterial to skin surface oxygen pressure gradient. A reference electrode (chest electrode) was placed between the scapulae to measure systemic changes in TcPO2 during exercise[2,5,6]. One electrode was positioned on each buttock, 4 to $5 \mathrm{~cm}$ behind the bony prominence of the trochanter, and one electrode on each calf. Once the electrodes were in position, a period of 10 minutes in the standing position was required to stabilize the electrodes to obtain baseline values. Exercise was performed on a treadmill at a $10 \%$ slope and a speed of up to $2 \mathrm{mph}$ [2]. Exercise was discontinued at the patient's request (or, by protocol, up to maximum 
exercise duration of 20 minutes). The measurements from the TcPO2 electrodes were used to calculate the Delta from Rest Oxygen Pressure (DROP) index (expressed in $\mathrm{mmHg}$ ). The equation for the DROP index is as follows[2]:

$$
\operatorname{DROP}_{\text {(site)= }}\left[\mathrm{PO}_{2 \text { (site) }} \mathrm{t}_{\mathrm{t}}-\mathrm{PO}_{2 \text { (site) }} \mathrm{t}_{0}\right]-\left[\mathrm{PO}_{2 \text { (chest) }} \mathrm{t}_{\mathrm{t}}-\mathrm{PO}_{2 \text { (chest) }} \mathrm{t}_{0}\right]
$$

where $\mathrm{PO}_{2(\text { site) }} \mathrm{t}_{\mathrm{t}}$ is the oxygen pressure at a measurement site at time $\mathrm{t}, \mathrm{PO}_{2(\text { site }} \mathrm{t}_{0}$ is the mean oxygen pressure at a measurement site over the baseline resting period; $\mathrm{PO}_{2(\text { chest })} \mathrm{t}_{\mathrm{t}}$ is the oxygen pressure at a chest site at time $\mathrm{t}$ and $\mathrm{PO}_{2 \text { (chest) }} \mathrm{t}_{0}$ is the mean oxygen pressure at a chest site over the resting period (2 min). We used the following procedure to analyze the raw data on each electrode using an excel spreadsheet. The system PF 6000 (TcPO2/CO2 Unit; Perimed@; Jarfalla, Sweden) records the value at 2Hz. Moving averaging over 10 samples was performed on raw data to decrease the electronic artifacts on the signal. Then the values were averaged over 2.5 -second interval. Additionally, on each 2.5-second interval, the TcPO2 values in each site were corrected. For this correction, we calculated the difference between the mean TcPO2 values over the 10 last seconds and over the first 2 minutes of the test. This difference was then divided by the duration of the test and the result was subtracted or added in each TcPO2 values as a weighting factor. Then the DROPs at each site were calculated. The DROPs indexes were also calculated using our in-house developed software, Oxymonitor®.

\section{Oxymonitor software}

Oxymonitor software is an in-house developed software that allows the analysis of the DROPs in realtime. The Oxymeter (TcPO2/CO2 Unit; Perimed ${ }^{\circledR}$; Jarfalla, Sweden) is plugged via USB on a laptop (Windows) where the Oxymonitor software is installed. At the beginning of the exercise test, the software begins to record the data.

\section{Statistical analysis}

The normality of the distribution was evaluated by Lilliefors goodness-of-fit test. Results are expressed as mean \pm standard deviation in case of normal distribution and as median $\left[25^{\text {th }} ; 75^{\text {th }}\right]$. The correlation between the spreadsheet DROP and the OxyMonitor DROP was evaluated using Spearman test. A DROP $\leq-16 \mathrm{mmHg}$ was defined to detect Peripheral artery disease (i.e. arterial stenosis $\geq$ 
60\%)[6]. The concordance between the spreadsheet DROP and Oxymonitor DROP to diagnose PAD was calculated using the Kappa test. A $p$ value $<0.05$ was considered as statistically significant.

\section{Results}

Data from 34 patients (mean age $64 \pm 2$ years old; $74 \%$ men) were analyzed. General characteristics of the population are presented in Table 1. The right and left mean ankle-brachial indexes at rest were $0.80 \pm 0.26$ and $0.79 \pm 0.24$, respectively. The median spreadsheet DROP and OxyMonitor DROP were 19[-29;-9] mmHg and -20[-29;-10] (non-significant). The correlation between the spreadsheet DROP and the OxyMonitor DROP was $\mathrm{R}^{2}=0.989(p<0.05$; Figure 1). The Kappa concordance test between the spreadsheet DROP and the Oxymonitor DROP was equal to 1.00 .

\section{Discussion}

A near perfect correlation and concordance were found between the spreadsheet DROP and the OxyMonitor DROP. As previously reported in this population, the sensitivity, specificity and accuracy of Exercise TcPO2 to diagnose arterial stenosis $\geq 60 \%$ were $80.4 \%$ [67.3-89.1], 88.2\% [64.2-97.7], and $82.4 \%$ [73.3-91.4], respectively[6]. The main advantage of Exercise TcPO2 is to allow measuring oxygen changes during exercise whereas other methods such as duplex or CTA can only perform a vascular assessment at rest. Although Exercise TcPO2 was seemed interesting, its use in clinical practice was probably hampered by the lack of dedicated software allowing the monitoring in realtime of the cutaneous oxygen changes. Our study suggests that the OxyMonitor software can be used to perform exercise oximetry in clinical routine for PAD diagnosis. We hope that manufacturers would develop their own software to develop the technique.

\section{Conflict of interest}

The authors declared they do not have anything to disclose regarding conflict of interest with respect to this manuscript. 


\section{FIGURE LEGEND}

FIGURE 1: Correlation between the exercise oximetry measures obtained with the spreadsheets and the Oxymonitor software.

DROP means Delta From Rest of Oxygen Pressure.

\section{REFERENCES:}

[1] P. Abraham, Y. Gu, L. Guo, K. Kroeger, N. Ouedraogo, P. Wennberg, S. Henni, Clinical application of transcutaneous oxygen pressure measurements during exercise, Atherosclerosis. (2018). doi:10.1016/j.atherosclerosis.2018.07.023.

[2] G. Mahe, M. Kalra, P. Abraham, D.A. Liedl, P.W. Wennberg, Application of exercise transcutaneous oxygen pressure measurements for detection of proximal lower extremity arterial disease: a case report, Vasc. Med. Lond. Engl. 20 (2015) 251-255. doi:10.1177/1358863X14567030.

[3] G. Mahé, A. Kaladji, A. Le Faucheur, V. Jaquinandi, Internal Iliac Artery Disease Management: Still Absent in the Update to TASC II (Inter-Society Consensus for the Management of Peripheral Arterial Disease), J. Endovasc. Ther. Off. J. Int. Soc. Endovasc. Spec. 23 (2016) 233-234. doi:10.1177/1526602815621757.

[4] G. Mahé, V. Jaquinandi, [Diagnosis of lower limb peripheral artery disease], Presse Medicale Paris Fr. 1983. (2017). doi:10.1016/j.lpm.2017.09.021.

[5] P. Abraham, J. Picquet, B. Vielle, D. Sigaudo-Roussel, F. Paisant-Thouveny, B. Enon, J.-L. Saumet, Transcutaneous oxygen pressure measurements on the buttocks during exercise to detect proximal arterial ischemia: comparison with arteriography, Circulation. 107 (2003) 1896-1900. doi:10.1161/01.CIR.0000060500.60646.E0.

[6] C. Koch, E. Chauve, S. Chaudru, A. Le Faucheur, V. Jaquinandi, G. Mahé, Exercise transcutaneous oxygen pressure measurement has good sensitivity and specificity to detect lower extremity arterial stenosis assessed by computed tomography angiography, Medicine (Baltimore). 95 (2016) e4522. doi:10.1097/MD.0000000000004522.

[7] S. Chaudru, P.-Y. de Müllenheim, A. Le Faucheur, A. Kaladji, V. Jaquinandi, G. Mahé, Training to Perform Ankle-Brachial Index: Systematic Review and Perspectives to Improve Teaching and Learning, Eur. J. Vasc. Endovasc. Surg. Off. J. Eur. Soc. Vasc. Surg. 51 (2016) 240-247. doi:10.1016/j.ejvs.2015.09.005.

[8] V. Aboyans, M.H. Criqui, P. Abraham, M.A. Allison, M.A. Creager, C. Diehm, F.G.R. Fowkes, W.R. Hiatt, B. Jönsson, P. Lacroix, B. Marin, M.M. McDermott, L. Norgren, R.L. Pande, P.-M. Preux, H.E.J. Stoffers, D. Treat-Jacobson, American Heart Association Council on Peripheral Vascular Disease, Council on Epidemiology and Prevention, Council on Clinical Cardiology, Council on Cardiovascular Nursing, Council on Cardiovascular Radiology and Intervention, and Council on Cardiovascular Surgery and Anesthesia, Measurement and interpretation of the anklebrachial index: a scientific statement from the American Heart Association, Circulation. 126 (2012) 2890-2909. doi:10.1161/CIR.0b013e318276fbcb. 
Table 1: Characteristics of the population studied

\begin{tabular}{|c|c|}
\hline Clinical characteristics & $n=34$ \\
\hline Age, years & $64 \pm 2$ \\
\hline Male sex, no. (\%) & $25(73.5 \%)$ \\
\hline Body mass index, $\mathrm{kg} / \mathrm{m}^{2}$ & $26.5 \pm 5.17$ \\
\hline \multicolumn{2}{|l|}{ Comorbidities, (history of), no. (\%) } \\
\hline Smoker (current or former) & $12(35 \%)$ \\
\hline Hypercholesterolemia & $8(23 \%)$ \\
\hline Diabetes & $7(21 \%)$ \\
\hline Peripheral artery disease & $11(32 \%)$ \\
\hline Hypertension & $24(71 \%)$ \\
\hline \multicolumn{2}{|l|}{ Current medications, no. (\%) } \\
\hline Statins & $20(59 \%)$ \\
\hline Antiplatelet & $28(82 \%)$ \\
\hline Others anticholesterolaemia & $8(23 \%)$ \\
\hline Angiotensin-converting enzyme inhibito & $18(53 \%)$ \\
\hline Ankle brachial index at rest (right) & $0.80 \pm 0.26$ \\
\hline Ankle brachial index at rest (left) & $0.79 \pm 0.24$ \\
\hline Maximal walking distance self-reported, $\mathrm{m}$ & $240 \pm 197$ \\
\hline Maximal treadmill walking distance, $\mathrm{m}$ & $241 \pm 236$ \\
\hline
\end{tabular}

Results are presented as mean \pm standard deviation or median $\left[25^{\text {th }} ; 75^{\text {th }}\right]$, or number of observation $(\%)$. 


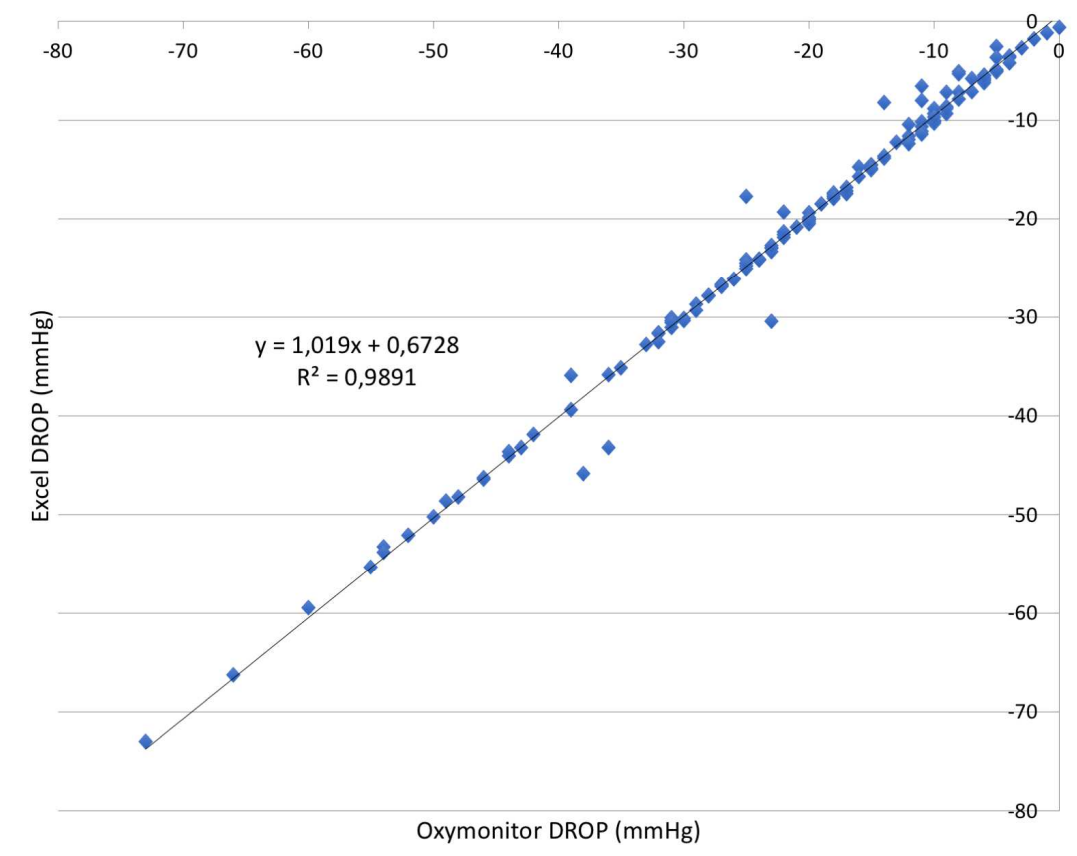

